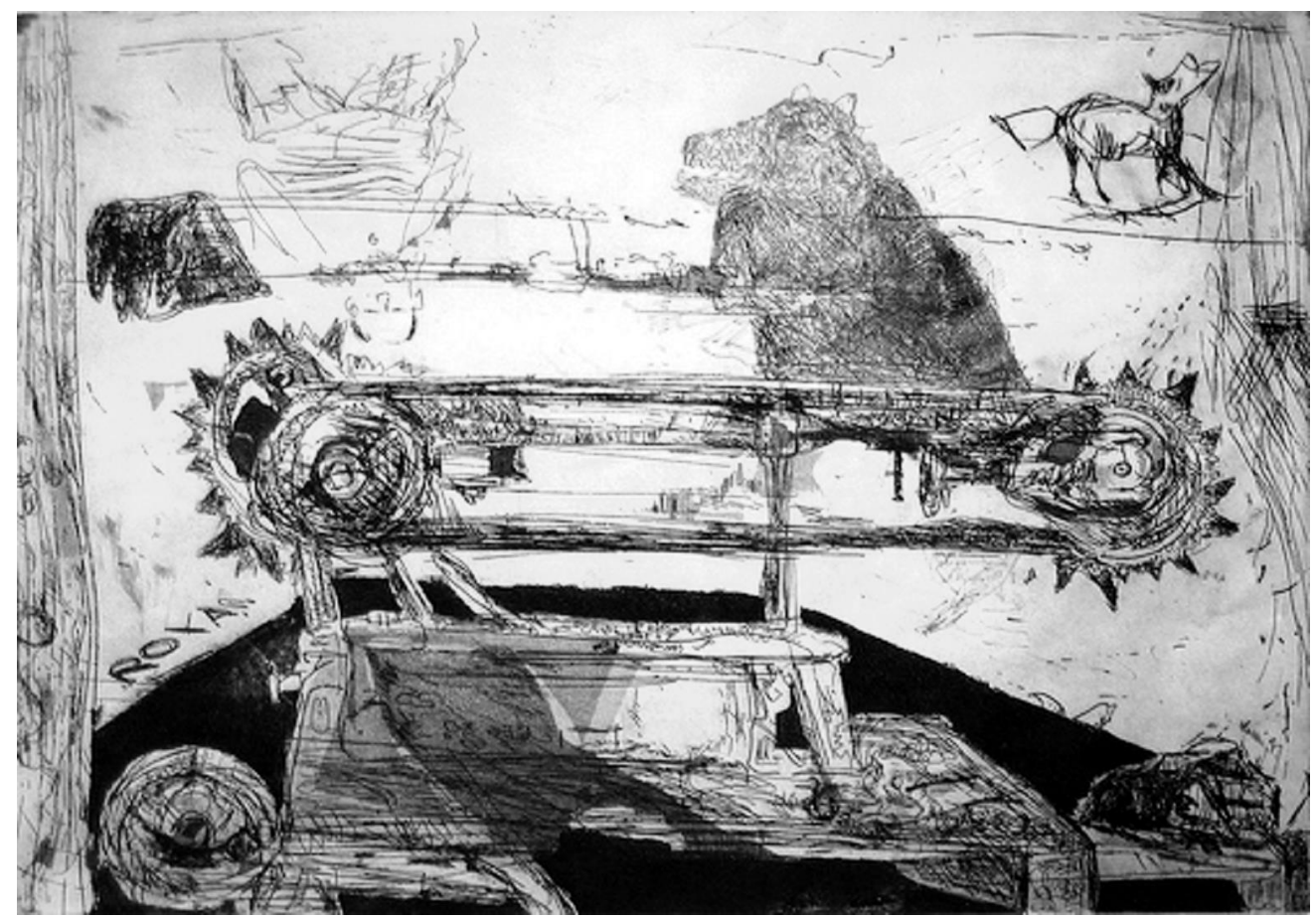

A máquina de triturar bois, de Leandro Figueiredo

\title{
Carne seca
}

\section{Affonso Romano de Sant'Anna}

Escritor brasileiro consagrado, foi cronista no Jornal do Brasil (1984-1988) e do jornal O Globo até 2005. Atualmente, escreve para os jornais Estado de Minas e Correio Brasiliense.

Hipocritamente durmo na madrugada enquanto bois são abatidos nos frigoríficos da manhã.

Durmo hipocritamente sem ver o sangue que escorre pelas calhas da noite e começam a subir, ondeando, pelos pés de minha cama. Durmo sem ver o olhar do boi no matadouro. O olhar. O berro. A morte.

Tapo os ouvidos, mas os grunhidos dos porcos rasgam o pêlo da noite. O sangue espirra do curral da madrugada e homens ávidos vão desenrolando as tripas da fera, que estrebucha, para convertê-las em linguiça que hipócrita e porcamente me serão servidas.

Uma vez contaram-me como se matam gansos na França. Os bois, a gente pode pensar, levam aquela pancada súbita na cabeça e desmontam sua carcaça no ladrilho. Mas os gansos são cevados, como se cevam os frangos. Os frangos sabem que vão morrer nos 
campos de concentração vigiados pela SS dos frigoríficos. Mas os gansos conhecem o martirológio dos santos e penitentes.

Começam a engordá-los. Ou, pior: cevá-los forçadamente. Os frangos, sabemos, são alimentados também artificiosamente; deixam aquelas luzes acesas noite e dia, e eles comendo, bicando, comendo, bicando os segundos, bicando os minutos numa engorda rápida e lucrosa.

Mas os gansos são agarrados à força. E então começa-se, por um funil, a socar para dentro deles a ração. Um funil ou moedor para que a comida já vá direta para dentro, chegue mais rapidamente ao fígado que, em forma de patê, colocarei em minha mesa no fim de semana na casa de campo. Mas não é sobre gansos que estou escrevendo especificamente e sim sobre a carne que para mim se prepara na escuridão hipócrita de minha fome.

$\mathrm{Na}$ infância de todo mundo (pelo menos no interior e antigamente) havia sempre uma galinha que alguém começou a matar na cozinha. E foi cortar o pescoço dela, tendo asas presas sob os pés contra o ladrilho, e, de repente ela se soltou. Se soltou e saiu com o pescoço pendurado jogando sangue pelas paredes até expirar no degrau para o quintal.

Há quem vá aos restaurantes especializados em peixes, porque quer ver o peixe vivo, o peixe que vai escolher no aquário. E aponta-lhe o dedo, "quero aquele ali", e se senta à mesa, enquanto na cozinha jogam lagostas vivas na água fervente e a champanha espuma sua indiferença na taça dos ricos.

Carne deveria dar em árvore.

Mas um dia me mostraram uma árvore que sangra. Meu caseiro espetava-lhe um prego, arame ou qualquer instrumento torturante, e lá vinha aquela gota vermelha. Não faz muito descobriram que os vegetais também são seres humanos. Já ouviram tomate chorar e laranjas terem vertigens quando colheram uma ao lado da outra na lâmina da morte.

E a esta hora estão pegando leitõezinhos que, assados, ainda ganham sobre o nariz uma rodela de laranja, e aqui e ali azeitonas e outros adereços. E hipocritamente me assento numa churrascaria. Bebo um chope junto com a caipirinha e peço voluptuosamente uma picanha. Por que não, um churrasco completo? Sim, aceito. E lá vêm os cadáveres eufóricos, correndo para o meu prato: tomo a faca, empunho o garfo como um guerreiro tártaro. E como. E como. E rumino. E mastigo. E gosto. O sangue da vítima vai se misturando ao meu civilizadamente. Barbaramente. 
Txt: Leituras Transdisciplinares de Telas e Textos, Belo Horizonte, v.5, n.9, p.81-83, 2009

o pior antropófago é o que tem remorsos de sobremesa.

Julho de 2007. 